\title{
MEASUREMENT OF LOGISTIC PERFORMANCE OF IMPORTED FROZEN MEAT IN PERUM BULOG
}

\author{
Rizki Nanditasari*)1, Sukardi**), and M. Syamsul Maarif*) \\ *) School of Business, IPB University \\ Jl. Pajajaran, Bogor 16151, Indonesia \\ **) Department of Agroindustrial Technology, Faculty of Agricultural Engineering and Technology, IPB University \\ Jl. Dramaga, PO BOX 220, Campus IPB Dramaga, Bogor 16602, Indonesia
}

\begin{abstract}
Perum BULOG received a mission to import frozen meat by the government in accordance with Presidential Regulation of the Republic of Indonesia Number 48 of 2016 . As a company engaged in food logistics, Perum BULOG is expected to be able to carry out imported frozen meat logistics activities to meet domestic needs. Logistics activities of imported frozen meat in Perum BULOG are divided into three stages, starting from the assignment mechanism, import mechanism, and sales mechanism. This causes the realization of frozen meat has not been achieved in accordance with the assignment. This study aims to measure the logistics performance of the imported frozen meat logistics activities carried out by the State Logistics Agency. The analytical method used the Logistic Scorecard Model, by identifying business strategies to obtain KPIs, and compiling logistical performance measurements. The results obtained by the logistics performance score of 2.691. This means that logistical performance for imported frozen meats run by Perum BULOG is at level 2, so Perum BULOG's logistics performance is poor. The improvement recommendation is by making a map of the frozen meat commodity business and making a direct shipping distribution strategy.
\end{abstract}

Keywords: activities of logistics, logistics performance measurement, logistic scorecard, perum bulog, frozen meat

\begin{abstract}
Abstrak: Perum BULOG mendapatkan penugasan untuk melakukan impor daging beku oleh pemerintah sesuai dengan Peraturan Presiden Republik Indonesia Nomor 48 Tahun 2016. Sebagai perusahaan yang bergerak di bidang logistik pangan, Perum BULOG diharapkan dapat menjalankan aktivitas logistik daging beku impor untuk memenuhi kebutuhan dalam negeri. Aktivitas logistik daging beku impor di Perum BULOG terbagi mejadi 3 (tiga) tahap, yang dimulai dari mekanisme penugasan, mekanisme impor, dan mekanisme penjualan Dalam menjalankan aktivitas logistiknya, Perum BULOG menghadapi beberapa kendala pada proses perencanaan dan pengendalian aliran barang. Hal ini menyebabkan belum tercapainya realisasi daging beku yang sesuai dengan penugasan. Penelitian ini bertujuan untukmnengukur kinerja logistik dari aktivitas logistik daging beku impor yang dijalankan oleh Perum BULOG. Metode analisis yang digunakan adalah Logistic Scorecard Model, dengan mengidentifikasi strategi bisnis untuk mendapatkan KPI, dan menyusun pengukuran kinerja logistik. Hasil penelitian diperoleh skor kinerja logistik sebesar 2,691. Artinya kinerja logistik untuk daging beku impor yang dijalankan oleh Perum BULOG berada pada level 2, artinya kinerja logistik Perum BULOG buruk. Rekomendasi perbaikan adalah dengan pembuatan peta bisnis komoditas daging beku dan membuat strategi distribusi direct shipping.
\end{abstract}

Kata kunci: aktivitas logistik, pengukuran kinerja, logistic scorecard, perum bulog, daging beku

\footnotetext{
${ }^{1}$ Corresponding author:

Email: rizkinanditasari@gmail.com
} 


\section{INTRODUCTION}

In recent years, the issue of food security is still an important issue in Indonesia. The government assigns BULOG Public Corporation based on the Republic of Indonesia Presidential Regulation No. 48 of 2016 to maintain food availability and stabilize food prices at both producer and consumer levels.

Based on the results of the Limited Coordination Meeting, Perum BULOG received an allocation of 100,000 tons of meat imports from India through two stages, 30,000 tons which had to be realized until December 2016, and 70,000 tons for reserve needs until the fasting month of 2017. As a company engaged in food logistics, Perum BULOG is expected to carry out imported frozen meat logistics activities to meet domestic demand.ogistics activities are part of supply chain management, incudling the planning, implementation and control of the flow of goods or services and related information, from the point of origin to the point of use to meet customer needs (Komara, 2014).

When received an import assignment, Perum BULOG did not have storage facilities. Therefore, Perum BULOG rented some cold storages around Jabodetabek. At present, there are 18 cold storages leased by Perum BULOG. Total capacity is 40,000 tons.

Based on data on the realization of meat imports, Perum BULOG has not been able to meet the amount of frozen meat that must be imported according to the quota. In addition, during the second phase, meat arrival exceeded cold storage capacity of 48,000 tons (Table 1).

Table 1 shows that the Phase I assignment, Perum BULOG was only able to realize the arrival of $9.998,722$ tons of frozen meat which should have brought 30,000 tons according to the assignment contents. Then, in the Phase II, Perum BULOG can only realized 48,272 tons which should bring about 70,000 tons. Based on these data, for the assignment of 100,000 tons Perum BULOG can only realize $58,270,772 \mathrm{~kg}$ of imported frozen meat. In addition, based on the results of interviews, in Phase II there was a problem where frozen buffalo meat came together as much as 48,000 tons. While the total cold storage capacity leased is 40,000 tons, so there is a build up of frozen meat at the port.

As a result, carrying out logistical activities of imported frozen meat PERUM BULOG still faces several obstacles in the process of planning and controlling the flow of goods. According to Linando (2013), in carrying out logistical activities so that the process can run effectively and efficiently. It is necessary to pay attention to the development of each aspect of the logistical activities. The logistic Scorecard tool was used to measure logistics performance This method utilised to find out the extent of the relationship of each of the aspects in the import frozen meat logistics activities carried out by the Bureau of Logistics, in order to meet the government assignment quota (Yose, 2015).

Previous research that discussed performance measurement was carried out by Purwantoro et al. (2018). Performance measurement is carried out using resources base view in analyzing the relationship between Porter's competitive strategy, company resources and performance. The results found that there are significant differences in performance between the strategy groups, companies in one strategy group have different configurations of resources. In addition, other research conducted by Harimurti (2018). The design of a measurement model for improving logistics system performance is based on the perspective of the Logistics Scorecard. The application of the model produces an average score of logistical performance which is quite good with several indicators that need to be improved.

Table 1. Recap of Perum BULOG Meat realization

\begin{tabular}{|c|c|c|c|c|c|}
\hline Description & Plan (ton) & Contract (ton) & Realize the arrival (ton) & Sales (ton) & Stock (ton) \\
\hline Buffalo meat (Phase I) & 30.000 & $9.998,764$ & $9.998,722$ & $7.411,534$ & $2.587,187$ \\
\hline Buffalo meat (Phase II) & 70.000 & 70.000 & 48.272 & 8.820 .000 & 39.452 \\
\hline Total & $79.998,764$ & $58.270,722$ & $16.231,534$ & $42.039,187$ & \\
\hline
\end{tabular}

Source: Perum BULOG (23 February 2017) 


\section{METHODS}

The research was conducted at Perum BULOG, Jakarta. The time of the study starts from August to September 2018. The data used consists of primary and secondary data. Primary data collection was conducted through in-depth interviews and direct observation, while secondary data ware carried out from company report data, books, journals and the internet. The sampling technique used in the study was purposive sampling. The number of speakers consisted of the Head of Procurement, Sales, and P2A Divisions, as well as the Director of Operations Perum BULOG, and Operations Director of PT. Prima Logistik Services. Data analyses were conducted in several stages, as follows:

\section{Identification Logistical Activities of Imported Frozen Meat at Perum BULOG}

Logistical activities of imported frozen meat were identified using descriptive analysis through interviews with several heads of divisions involved in logistical activities of imported frozen meat, namely the procurement division, sales division, and business development division. This stage aims to describe the flow of logistics activities.

\section{Logistics Performance Measurement}

\section{a. Analysis of External and Internal Factors}

Analysis of external factors were to produce a list of opportunities and threats for the company. Internal factor analysis is conducted by functional analysis of the company, namely aspects of organization, marketing, finance, production / operations, and human resources (Sumarwan, 2014).

b. TOWS (Threats, Opportunities, Weaknesses, Strengths) Analysis

After obtaining the list of external and internal factors, the next step is to formulate a strategy using TOWS matrix analysis (David, 2010).

\section{c. Weighting of Key Performance Indicators (KPI)}

After the logistical KPI was identified, the weighting of each KPI is then carried out to determine the priority order of the KPI (Darmanto, 2014). Weighting is calculated using the Analitycal Hierarchy Process (AHP) method.

d. Developing a logistical performance measurement matrix

After weighting the KPI, the KPI priorities are determined based on the highest final weight of each KPI, and the scale of assessment to measure logistical performance. The rating scale used is a descriptive rating scale type, with a scale of 1 to 5 (Wibowo, 2017). For each target of the KPI defined how the lowest level is represented by level 1, up to the highest level represented by a scale of 5 (Sasongko, 2017).

e. Fill out the Logistics Performance Measurement Matrix

The input for filling the matrix is to choose a scale of 1-5, which illustrates the current state of logistics activities for imported frozen meat. The matrix calculation process is multiplying the scale value with the weight of the KPI. The result is a score for each KPI and a total overall logistical performance score. The method of determining the score for each KPI is the average result of the number of respondents (Makkasau, 2012). This score is then classified according to the logistical performance score category at the level $1,2,3,4$, or 5 (Sosyalaras, 2017). This level shows the logistical performance position of imported frozen meat run by the Public Corporation of Logistics Bureau. The grouping of categories for performance scores based on scale values are as follows: Level 1 (Logistics performance is very poor, where the company is not involved in logistics activities); Level 2 (Poor logistics performance); Level 3 (Logistics performance is good enough but still needs improvement); Level 4 (Good logistics performance); Level 5 (Excellent logistics performance).

The way to fill in the matrix is that each KPI is defined as the lowest level, which is represented by a scale of 1 and the highest level is represented by a scale of 5. The value of this scale shows the conditions of the company's logistical achievements for each KPI. Furthermore, the calculation of the scale value of $x$ weight KPI, to get the total performance score, which shows the position of logistics performance frozen beef import Perum BULOG at what level. The conceptual framework for this research can be seen in Figure 1. 


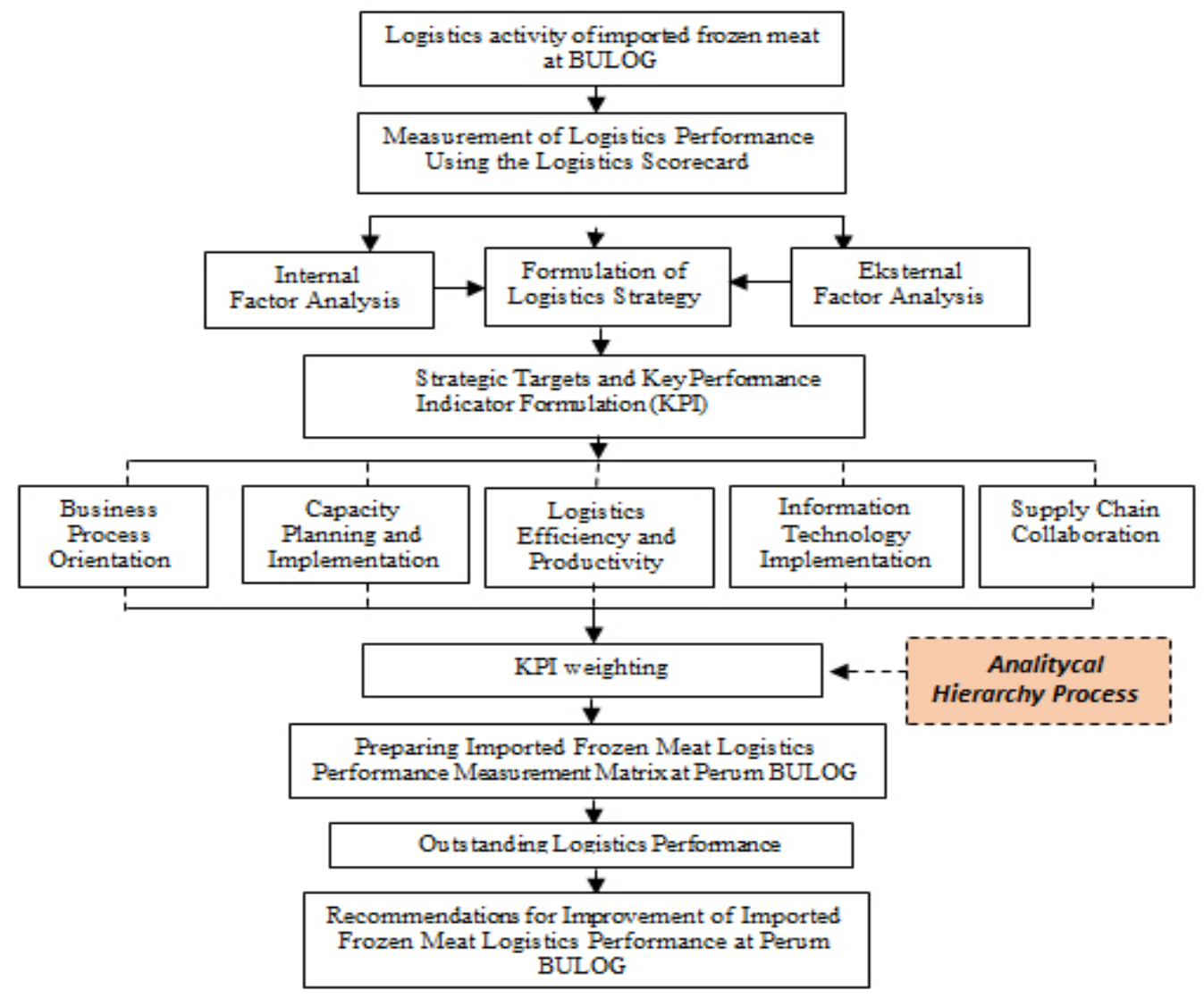

Figure 1. Research framework

\section{RESULTS}

\section{Logistics activity of Frozen Meat Import in Perum BULOG}

Logistics activities are part of supply chain management which includes the process of planning, implementing, controlling the flow of goods or services and related information, starting from the point of origin to the point of use to meet customr needs (Sutanto, 2014). Based on the Standard Operating Procedures (SOP) in Perum BULOG, the logistics activities of imported frozen meat are divided into three stages, including the assignment mechanism, import mechanism, and sales mechanism (Figure 2).

Based on Figure 2, the logistics activities of imported frozen meat carried out by Perum BULOG begins with a Limited Coordination Meeting in the field of food led by the Coordinating Minister of Economic Affairs and attended by the Minister of Agriculture, the Minister of Trade, the Minister of State Owned Enterprises (SOEs), the Minister of Finance, and the Managing Director of BULOG. The meeting resulted in the decision to assign Perum BULOG to meet the supply of healthy and cheap meat in the context of stabilizing meat prices, by providing an import quota of 100.000 tons.

After Perum BULOG received the assignment, the Staple Food Procurement Division then requested technical recommendations from the Ministry of Agriculture to obtain a list of suppliers, fulfilled animal health, hygienic and halal requirements, and to conduct the tender process. The Ministry of Agriculture recommended several suppliers from India who sell buffalo meat. According to The Ministry of Agriculture, Indian buffalo meat meets healthy, hygienic and halal meat specifications. The next step, the suppliers were contacted to make a Request For Quotations (RFQ). In the RFQ, Perum BULOG asks for the completeness of document requirements in order to find out the total production capacity, halal certificate, supporting documents, and price indications or prices offered. Based on this RFQ, Public Corporation Bulog determine which suppliers meet the qualifications. After passing RFQ, suppliers will offers via email for price negotiations. If a price agreement has been made, the suppliers then will order. 
The order period until the frozen meat arrives is 14 days. After the frozen meat arrives at the Port of Tanjung Priok, the next step is the administration of import clearance (import clearance, quarantine and customs fees). After that, the unloading is carried out from the dock to the cold storage. As Perum BULOG does not have cold storage, Perum BULOG distributes the meat to each rented cold storage. After the meat is stored, Bulog will sell it. The sales system conducted by distributors.

\section{Internal and External Strategic Factors}

Internal factor analysis resulted lists of strengths and weaknesses of the company. While, analysis of external factors resulted lists of opportunities and threats for the company (Setiadi, 2014). The lists of internal and external factors analysis in the TOWS matrix analysis have been generated (Table 2). The TOWS matrix analysis also provide alternative strategies for companies.
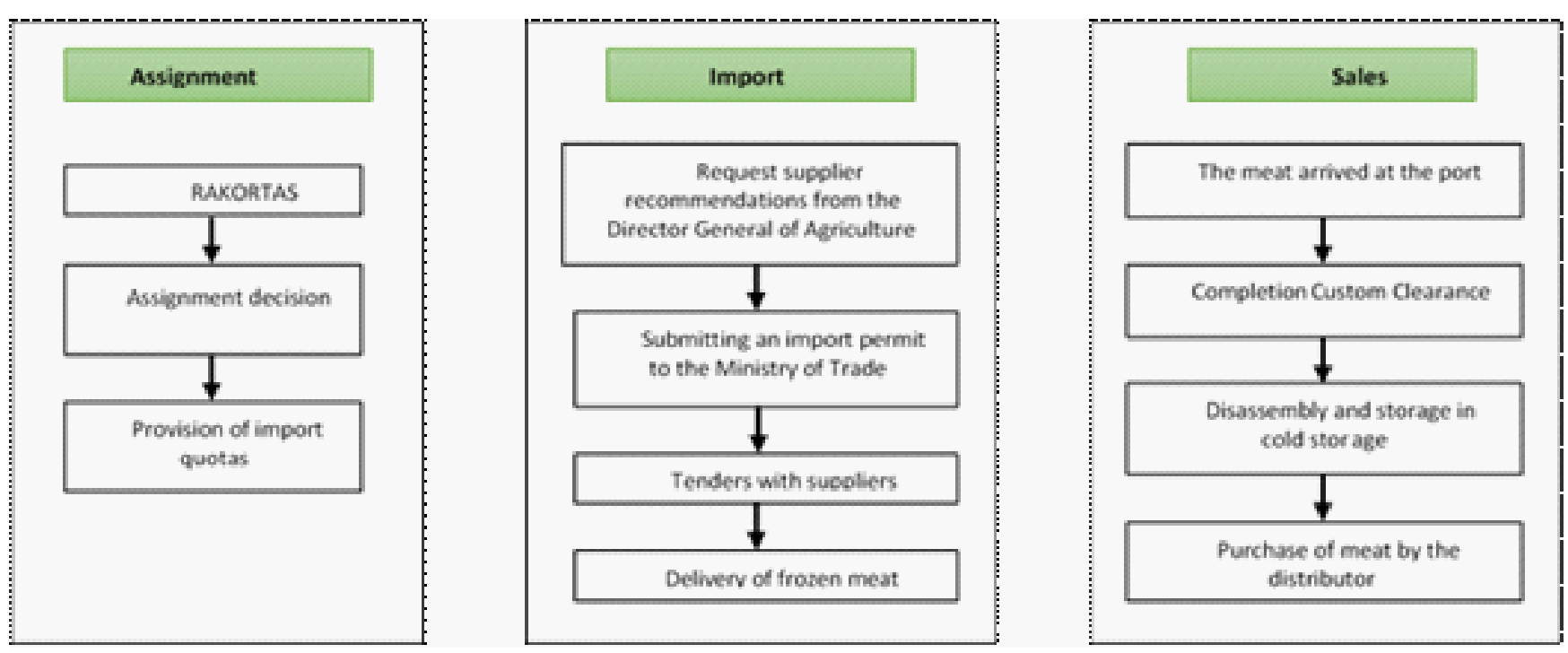

Figure 2. Logistics activity of imported frozen meat in BULOG

Table 2. TOWS Analysis

\begin{tabular}{|c|c|c|}
\hline & Strength (S) & Weakness (W) \\
\hline & $\begin{array}{l}\text { 1. Perum BULOG Receives Assignment } \\
\text { from the Government as Food Reserve } \\
\text { Manager } \\
\text { 2. Perum BULOG already has experience to } \\
\text { maintain food security } \\
\text { 3. Having a fairly extensive network in all } \\
\text { regions of Indonesia }\end{array}$ & $\begin{array}{l}\text { 1. Procurement Planning Mechanisms and Processes are } \\
\text { inaccurate and not yet comprehensive } \\
\text { 2. Limitations of cold storage facilities } \\
\text { 3. BULOG does not have good logistics management } \\
\text { for frozen meat imports } \\
\text { 4. The lack of use of technology for the import of frozen } \\
\text { meat logistics activities }\end{array}$ \\
\hline Opportunities (O) & Strategi S-O & Strategi W-O \\
\hline $\begin{array}{l}\text { 1. The meat market is still wide } \\
\text { open } \\
\text { 2. Access to domestic and } \\
\text { foreign producers } \\
\text { 3. Opened business cooperation } \\
\text { with food industry players } \\
\text { and food commodity } \\
\text { suppliers, both from domestic } \\
\text { and abroad }\end{array}$ & $\begin{array}{l}\text { - Market intelligence development (S1, S2, } \\
\text { S3-O1, O2, O3) } \\
\text { - Create a business development strategy } \\
\text { (S2, S3-O1,O2,O3) } \\
\text { - Develop collaboration with supplier } \\
\text { (S2,S3-O1, O2,O3) } \\
\text { - Building a business with performance and } \\
\text { capability based partners for procurement } \\
\text { and sales (S1, S2, S3-O1, O2, O3) }\end{array}$ & $\begin{array}{l}\text { - Develop a frozen meat logistics network . (W3, W4- } \\
\text { O1,O2,O3) } \\
\text { - Establish SOP for frozen meat logistics (W1,W3,W4- } \\
\text { O1,O2,O3) } \\
\text { - Develop utilization \& investment plans (W1,W2,W3- } \\
\text { O1,O2,O3) } \\
\text { - Increasetheuse of SIMthroughinformationtechnology } \\
\text { in management functions (W3-O1,O2,O3) } \\
\text { - Establish SOP integration between IT based } \\
\text { procurement, storage and sales (W3-O1,O2) } \\
\text { - Improve human resource and management capabilities } \\
\text { for frozen meat commodities (W4-O1) }\end{array}$ \\
\hline Threats $(\mathrm{T})$ & Strategi S-T & Strategi W-T \\
\hline $\begin{array}{l}\text { 1. The possibility of other } \mathrm{SOE} \\
\text { receiving import quotas from } \\
\text { the government } \\
\text { 2. Community response to } \\
\text { buffalo meat }\end{array}$ & $\begin{array}{l}\text { - Creating a business development strategy } \\
(\mathrm{S} 2, \mathrm{~S} 3-\mathrm{T} 1) \\
\text { - Improve understanding \& application of } \\
\text { risk management in each unit }(\mathrm{S} 2, \mathrm{~T} 1, \mathrm{~T} 2)\end{array}$ & $\begin{array}{l}\text { - Develop customer handling centers (W1,W3-T2) } \\
\text { - Negotiating with suppliers to get the best price } \\
\text { (W2,W3-T1) }\end{array}$ \\
\hline
\end{tabular}




\section{Key Performance Indicators (KPI) Based on the Logistic Scorecard Perspective}

After determining the strategies generated from the TOWS analysis, the next step is to identify performance indicators and their targets based on Logisctic Scorecard perspective. This perspective was obtained from Long Term Planning 2016-2020 (Table 3)

\section{Logistic KPI Weighting Based on the Logistic Scorecard Perspective}

The scorecard KPI resulted from logistic perspective, the next step is weighting of each KPI. The weighting was used AH (Rahardjo, 2017) with the help of Expert Choice 11 sofware. The steps are as follows:
1. Creating a hierarchical structure that starts with general objectives, followed by determining the criteria, namely logistic scorecard perspectives and $\mathrm{KPI}$; and

2. Making a pairwise comparison matrix in the form of a questionnaire whose contents assess the level of importance from one perspective compared to other perspectives, as well as one KPI with another KPI. This questionnaire was filled in by experts from BULOG Public Corporation.

Weighting was conducted done using the help of Expert Choice 11 software KPI is weighted using the Analyticalcal Hierarchy Process (AHP) method with the help of Expert Choice 11 software, which is shown in Table 4.

Table 3. Perspectives, indicators, targets of the startegy

\begin{tabular}{|c|c|c|c|}
\hline Perspective & Strategy & Indicator & Target \\
\hline Bisnis Orientation & $\begin{array}{l}\text { 1. Develop market intelligence } \\
\text { 2. Creating a development strategy } \\
\text { 3. Increase the ability of human } \\
\text { resources and management for } \\
\text { frozen meat commodities }\end{array}$ & $\begin{array}{l}\text { 1. Map of the frozen meat } \\
\text { commodity business } \\
\text { 2. Business diversification } \\
\text { 3. Strengthening human } \\
\text { resources }\end{array}$ & $\begin{array}{l}\text { 1. } \% \text { of Perum BULOG ownership } \\
\text { of the frozen meat business map } \\
\text { 2. Frozen meat has become one of } \\
\text { the core businesses of the State } \\
\text { Logistics Agency (Bulog) } \\
\text { 3. The handling of frozen } \\
\text { meat commodities is more } \\
\text { professional }\end{array}$ \\
\hline $\begin{array}{l}\text { Capacity } \\
\text { Planning and } \\
\text { Impelementation }\end{array}$ & $\begin{array}{l}\text { 1. Develop a logistics network for } \\
\text { frozen meat } \\
\text { 2. Establish SOP for imported frozen } \\
\text { meat logistics } \\
\text { 3. Develop a center for handling } \\
\text { consumer complaints }\end{array}$ & $\begin{array}{l}\text { 1. Fulfilled Cold chain frozen } \\
\text { meat } \\
\text { 2. SOP-based imported frozen } \\
\text { meat logistics } \\
\text { 3. Numberofpublic complaints } \\
\text { in each period }\end{array}$ & $\begin{array}{l}\text { 1. Have a frozen meat sales } \\
\text { network } \\
\text { 2. Have a strategic business plan for } \\
\text { imported frozen meat } \\
\text { 3. The public will get information } \\
\text { about the availability of frozen } \\
\text { meat of the State Logistics } \\
\text { Agency (Bulog) in the market }\end{array}$ \\
\hline $\begin{array}{l}\text { Logistics } \\
\text { Efficiency and } \\
\text { Productivity }\end{array}$ & $\begin{array}{l}\text { 1. Develop a plan for utilization and } \\
\text { investment } \\
\text { 2. Negotiating with suppliers to get } \\
\text { the best price } \\
\text { 3. Improve understanding and } \\
\text { application of risk management in } \\
\text { each work unit }\end{array}$ & $\begin{array}{l}\text { 1. Infrastructure-based } \\
\text { activities develop } \\
\text { 2. The best purchase price for } \\
\text { frozen meat } \\
\text { 3. Number of work units } \\
\text { that implement risk } \\
\text { management }\end{array}$ & $\begin{array}{l}\text { 1. Development of cold storage } \\
\text { 2. Getting the price of buying cheap } \\
\text { meat with the same quality } \\
\text { 3. Each line of management applies } \\
\text { risk management }\end{array}$ \\
\hline $\begin{array}{l}\text { Technology } \\
\text { Implementation }\end{array}$ & $\begin{array}{l}\text { 1. Increase the utilization of } \\
\text { Management Information Systems } \\
\text { through information technology } \\
\text { in the logistics management } \\
\text { function. } \\
\text { 2. Establish SOP integration between } \\
\text { IT-based procurement, storage and } \\
\text { sales }\end{array}$ & $\begin{array}{l}\text { 1. Number of logistics } \\
\text { management functions } \\
\text { that utilize Management } \\
\text { Information Systems (SIM) } \\
\text { 2. Modern stock management } \\
\text { (saving and timely) }\end{array}$ & $\begin{array}{l}\text { 1. All logistics management } \\
\text { functionsimplementManagement } \\
\text { Information Systems } \\
\text { 2. Digitalization of logistics } \\
\text { information systems }\end{array}$ \\
\hline $\begin{array}{l}\text { Supply Chain } \\
\text { Collaboration }\end{array}$ & $\begin{array}{l}\text { 1. Plan procurement according to } \\
\text { sales needs } \\
\text { 2. Develop cooperation with } \\
\text { suppliers } \\
\text { 3. Building a business with partners } \\
\text { based on performance \& capability } \\
\text { for procurement \& sales }\end{array}$ & $\begin{array}{l}\text { 1. Matching the number of } \\
\text { procurement with sales } \\
\text { 2. Achieving sales targets } \\
\text { 3. Cooperation partners are } \\
\text { adequate and reliable }\end{array}$ & $\begin{array}{l}\text { 1. Stock as minimal as possible } \\
\text { 2. The achievement of the } \\
\text { assignment mission } \\
\text { 3. Increased sales performance of } \\
\text { frozen meat }\end{array}$ \\
\hline
\end{tabular}


Table 4. Weigthed KPI

\begin{tabular}{|c|c|c|c|c|}
\hline Perspevtives & $\begin{array}{l}\text { Weigted } \\
\text { Perspective }\end{array}$ & Indicators & $\begin{array}{l}\text { Weigted } \\
\text { Criteria }\end{array}$ & $\begin{array}{l}\text { Final weighted } \\
\text { criteria }\end{array}$ \\
\hline \multirow{3}{*}{$\begin{array}{l}\text { Business Strategy } \\
\text { Orientatiom }\end{array}$} & \multirow[t]{3}{*}{0.07} & Business map of frozen meat commodities & 0.10 & 0.007 \\
\hline & & Business Diversification & 0.30 & 0.021 \\
\hline & & Strengthening human resources & 0.60 & 0.042 \\
\hline \multirow{3}{*}{$\begin{array}{l}\text { Capacity Planning } \\
\text { and Implementation }\end{array}$} & \multirow[t]{3}{*}{0.11} & Fulfilled frozen meat cold chain & 0.10 & 0.011 \\
\hline & & Establish SOP for logistics meat & 0.30 & 0.033 \\
\hline & & $\begin{array}{l}\text { Developing a center for handling consumer } \\
\text { complaints }\end{array}$ & 0.60 & 0.066 \\
\hline \multirow{3}{*}{$\begin{array}{l}\text { Logistics Efficiency } \\
\text { and Productivity }\end{array}$} & \multirow[t]{3}{*}{0.15} & Infrastructure based develop activities & 0.10 & 0.015 \\
\hline & & The best purchase price for frozen meat & 0.32 & 0.048 \\
\hline & & $\begin{array}{l}\text { Number of work units implementing risk } \\
\text { management }\end{array}$ & 0.58 & 0.087 \\
\hline \multirow{2}{*}{$\begin{array}{l}\text { Information } \\
\text { Technology } \\
\text { Implementation }\end{array}$} & \multirow[t]{2}{*}{0.27} & $\begin{array}{l}\text { Management functions that utilize management } \\
\text { information systems }\end{array}$ & 0.26 & 0.070 \\
\hline & & Modern stock management & 0.74 & 0.199 \\
\hline \multirow{3}{*}{$\begin{array}{l}\text { Supply Chain } \\
\text { Collaboration }\end{array}$} & \multirow[t]{3}{*}{0.40} & Matching procurement amount with sales & 0.12 & 0.048 \\
\hline & & Achieving sales targets & 0.26 & 0.104 \\
\hline & & Cooperation partners are adequate and reliable & 0.62 & 0.248 \\
\hline
\end{tabular}

\section{Logistics Performance Measurement Metrics Using the Logistics Scorecard}

After getting the weight of each Key Performance Indicator (KPI), the next priority is to determine the KPI as described in Table 5. After prioritizing KPI, the next step is to develop logistics performance metrics using a logistic scorecard. Determining the rating scale used a descriptive rating scale for each KPI (Yose, 2015). Table 6 shows the results of the calculation of the logistical performance measurement matrix based on the assessment of the five respondents.

Based on the results of filling out the logistics performance measurement metrics, the total logistical performance scores owned by Public Corporation Bulog accounted to 2.691. This score shows the logistics performance of imported frozen meat carried out by Perum BULOG at level 2 (poorm performance). The average value for each KPI not yet reaching the value of 5 . It means that KPI set by Perum BULOG has not reached the target. Of the 14 KPIs, there are two KPIs that have low score and weight score, namely the frozen meat commodity business map of 0.007 and the fulfillment of frozen cold chain cold meat of 0.033 . As a result, the two KPIs should be priority to improve.

\section{Managerial Implications}

Recommendations for improvements to the logistics performance of the Bureau of Logistics are based on the low average score of KPIs .Of the 14 KPIs, there are two KPIs with the low average score, namely the frozen meat commodity business map of 0.007 and the fulfillment of cold chain frozen meat of 0.033 . Hence, the two lowest KPIs are recommended to address, for improving the logistics performance of frozen meat imported. The results of this study are expected to be used as a reference for improving the performance of Logistics Bureau. Some improvements include making a map of the frozen meat commodity business. The business map contains the planning stages of activities that will be carried out for the assignment of frozen meat imports. In addition, business maps can integrate the planning, monitoring and evaluation processes, as well as supply chain collaboration along logistical activities, so as to minimize the risks involved in carrying out imported frozen meat assignments (Samekto, 2014). Therefore, the map of imported frozen meat business should contains SOP for frozen meat logistics activities that consist of: (1) the inbound logistic process; the flow of frozen meat from the supplier to the storage warehouse, (2) the outbound logistic process: the movement of frozen meat flow in the storage warehouse, and (3) the outbound logistic process: the movement of frozen meat from the warehouse to the consumer (Mulyadi, 2011). 
Tabel 5. Priority of Key Performance Indicator (KPI)

\begin{tabular}{lc}
\hline \multicolumn{1}{c}{ KPI } & Weight \\
\hline Cooperation partners are adequate and reliable & 0.248 \\
Modern stock management & 0.199 \\
Achieving sales targets & 0.104 \\
Number of work units implementing risk management & 0.087 \\
Management functions that utilize management information systems & 0.070 \\
Develop a center for handling consumer complaints & 0.066 \\
Matching procurement amount with sales & 0.048 \\
The best purchase price for frozen meat & 0.048 \\
Strengthening human resource & 0.042 \\
Establish SOP for frozen meat logistics & 0.033 \\
Business diversifications & 0.021 \\
Infrastructure based activities develop & 0.015 \\
Fulfilled frozen meat cold chain & 0.011 \\
Business map of frozen meats & 0.007 \\
\hline
\end{tabular}

Table 6. Result of calculation of logistics performance measurement matrix

\begin{tabular}{lccc}
\hline \multicolumn{1}{c}{ KPI } & Average Value & Weight & Average Score \\
\hline Cooperation partners are adequate and reliable & 4 & 0.248 & 0.992 \\
Modern stock management & 2 & 0.199 & 0.597 \\
Achieving sales targets & 2 & 0.104 & 0.208 \\
Number of work units implementing risk management & 2 & 0.087 & 0.174 \\
Management functions that utilize management information system & 2 & 0.070 & 0.140 \\
Develop a center for handling consymer complaints & 4 & 0.066 & 0.264 \\
Matching procurement amount with sales & 1 & 0.048 & 0.048 \\
The best purchase price for frozen meat & 3 & 0.048 & 0.144 \\
Strengthening human resources & 3 & 0.042 & 0.126 \\
Establish SOP for frozen meat logistics & 1 & 0.042 & 0.042 \\
Business diversification & 3 & 0.021 & 0.063 \\
Infrastructure based activities develop & 3 & 0.015 & 0.045 \\
Fulfilled frozen meat cold chain & 3 & 0.011 & 0.033 \\
Business map of frozen meat & 1 & 0.007 & 0.007 \\
\hline \multicolumn{1}{c}{ TOTAL SCORE } & & 2.691 \\
\hline
\end{tabular}

The second is developing the Direct Shipping distribution strategy by building a distribution center. This strategy support the indicators of the fulfillment of frozen meat cold chain in BULOG Public Corporation. Implementation the strategy is expected to be able to streamline and streamline the logistics activities of imported frozen meat in terms of regulating the flow of goods, inventory and sales (Wiedjanarko, 2015). Therefore, a distribution center would avoid the buildup of frozen meat in the harbor.

\section{CONCLUSIONS AND RECOMMENDATIONS}

\section{Conclusions}

The logistics activities of imported frozen meat carried out by Perum BULOG is divided into three stages, starting with the assignment mechanism, import mechanism, and sales mechanism. These activities has been carried out in accordance with the company's SOP. Based on the results of logistical performance measurements, the total score owned by the Bureau of Logistics is 2.691. This score shows the logistics 
performance of imported frozen meat run by the State Logistics Agency of Bulog is at level 2 (poor performance). Logistics performance would improve through business map of the frozen meat and the fulfillment of the cold chain. Recommendations for improvement are designed by a map of the imported frozen meat business and direct shipping distribution strategy.

\section{Recommendations}

Further research needs to formulate a strategy to carry out logistics activities for frozen meat, KPIs, and their targets in more detail. The detailed strategies would assist to achieve KPIs and targets. In addition, the result of research can be used by Perum to improve the logistics activities of imported frozen meat.

\section{REFERENCES}

Darmanto E. Penerapan metode analythic hierarcy process untuk menentukan kualitas gula tumbu. Jurnal SIMETRIS 5(1) : 75-82. https://doi. org/10.24176/simet.v5i1.139.

David. 2010. Manajemen Strategis Konsep. Jakarta: Salemba Empat.

Harimurti C. 2018. Model Peningkatan Kinerja Sistem Logistik yang Efektif dan Efisien. Jurnal Logistik Indonesia 1(1) : 46-68. https://doi.org/10.31334/ jli.v1i1.127.

Komara J. 2014. Studi Deskriptif Aktivitas Inbound Outbond Logistik Pada UD Sumber Baru di Jember [Tesis]. Surabaya: Universitas Surabaya.

Linando A. 2013. Perancangan sistem pengukuran dan perbaikan kinerja logistik pada industri makanan ringan di CV. XYZ Surabaya. Journal of Logistics Supply Chain Management 3(3) : 144-156.

Makkasau K. 2012. Penggunaan Metode Analytic Hierarchy Process (AHP) dalam Penentuan Prioritas Program Kesehatan (Studi Kasus Program Promosi Kesehatan) [Tesis]. Semarang: Universitas Diponegoro.

Mulyadi D. 2011. Pengembangan sistem logistik yang efisien dan efektif dengan pendekatan supply chain management. Jurnal Riset Industri 5(3):

\section{5-282.}

Purwantoro. 2018. Strategi bersaing dan pengukuran kinerja dengan pendekatan resources base view perusahaan komponen otomotif Indonesia. Jurnal Aplikasi Manajemen Bisnis 4(2) : 220231. https://doi.org/10.17358/jabm.4.2.220.

Rahardjo B. 2017. Perancangan sistem manajemen gudang material penunjang di PT XYZ. Jurnal Teknik Industri 12 (2) : 127-136. https://doi. org/10.14710/jati.12.2.127-136.

Samekto A, Soejanto. 2014. Strategi meningkatkan kinerja perusahaan melalui diversifikasi usaha studi empiric pada perusahaan ekspedisi muatan kapal laut PT. Teduh Makmur, Semarang. Jurnal Manajemen Transportasi \& Logistik 1(1): 1-15.

Sasongko A, Astuti I, Maharani S. 2017. Pemilihan karyawan baru dengan metode AHP (Analytic Hierarchy Process). Jurnal Informatika Mulawarman 12(2): 15-25. https://doi. org/10.30872/jim.v12i2.650.

Setiadi N. 2014. Studi Deskriptif Aktivitas Logistik Inbound Outbond Pada PT Sinar Cahaya Cemerlang di Surabaya [Tesis]. Surabaya: Universitas Surabaya.

Sosyalaras. 2017. SWOT analysis : a theoretical review. The Journal of International Social Research 10(51):997-1006.https://doi.org/10.17719/ jisr.2017.1832.

Sumarwan U. 2014. Metode Riset Bisnis dan Konsumen. Bogor: IPB Press.

Sutanto MR, Jacky SB, Sumarauw. 2014. Evaluasi Kinerja Sistem Logistik Pada Perusahaan Vulkanisir UD. Sumber Ban Tateli. Jurnal EMBA 2(3) : 588-596.

Wibowo W. 2017. Sistem angkutan multimoda dalam mendukung efisiensi biaya logistik di Indonesia. Jurnal Manajemen Transportasi \& Logsitik 4(1): 25-38. https://doi.org/10.25292/j.mtl.v4i1.48.

Wiedjanarko S. 2015. Strategi distribusi produk tej siap saji. Jurnal Manajemen \& Agribisnis 12(1): 6877. https://doi.org/10.17358/JMA.12.1.68.

Yose M. 2015. Model pengukuran kinerja logistik industri komponen otomotif untuk penguatan daya saing dalam rangka menghadapi MEA. Jurnal Teknik Industri 4(60): 86-100. 